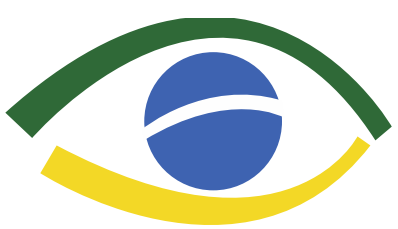

\section{Observatório da Jurisdiçãc Constitucional}

Observatório da Jurisdição Constitucional. Ano 7, no. 2, jul./dez. 2014. ISSN 1982-4564.

\title{
Uma leitura hermenêutica das características do neoconstitucionalismo
}

\author{
Lenio Luiz Streck
}

\begin{abstract}
Resumo dos editores: Neste artigo, Lenio Luiz Streck marca sua posição teórica sobre o positivismo, o neoconstitucionalismo e o jusnaturalismo. Nenhuma dessas vertentes traz perspectivas adequadas para compreender o Constitucionalismo Contemporâneo, que tem por conteúdo essencial a matriz democrática da formulação normativa: ora elas negam a própria possibilidade de uma teoria da decisão, ora adotam uma teoria da decisão que encampa e enquadra o decisionismo principialista. A virada teórica neoconstitucionalista despertou um saudável incômodo quanto à interpretação jurídica, o qual deve se agregar em torno de uma teoria póspositivista que dê ao direito um papel socialmente ativo no marco das virtudes soberanas constitucionais.
\end{abstract}

Palavras-chave: Positivismo, Jusnaturalismo, Neoconstitucionalismo, Constitucionalismo Contemporâneo, PósPositivismo, Teoria da Decisão, Hermenêutica Jurídica.
Editors' Abstract. In this article Professor Lenio Luiz Streck marks his standpoint regarding positivism, neoconstitutionalism and naturalism. None of these perspectives can aptly describe "Contemporary Constitutionalism", which considers that norms are democratically formulated: they either deny the possibility of building a theory of legal decisionmaking or consider that discretion is the side-effect of a principle-laden approach. Neoconstitutionalism has awoken concerns over legal interpretation which should be taken up by a post-positivist theory that assures that law is socially-minded and respects sovereign virtues.

Keywords:

Positivism, Neoconstitutionalism, Contemporary Constitutionalism, Post-Positivism Constitutionalism, Decision-making theories, Legal Interpretation.

* Doutor em Direito (UFSC); Pós-doutor em Direito (Universidade de Lisboa); ExProcurador de Justiça-RS; Professor da UNISINOS-RS e UNESA-RJ; Professor Visitante da Universidades Javeriana (CO) e Roma TRE (IT); Membro Catedrático da ABDCONST Academia Brasileira de Direito Constitucional; Presidente de Honra do IHJ - Instituto de Hermenêutica Jurídica. 


\section{Introdução}

Em tempos pós-positivistas - ou de fortes críticas aos diversos positivismos -, é absolutamente relevante discutirmos as condições de possibilidade que a teoria do direito possui para construir respostas aos grandes dilemas surgidos com o advento do assim denominado neoconstitucionalismo.

É nesse sentido que, já de pronto, é preciso ter presente que o termo neoconstitucionalismo incorpora em si uma plêiade de autores e posturas teóricas que nem sempre podem ser aglutinadas em um mesmo sentido. A ciência política norte-americana, por exemplo, chama de new constitutionalism os processos de redemocratização que tiveram lugar em vários países da chamada modernidade periférica nas últimas décadas. Entre esses países é possível citar o Brasil, a Argentina, os países do leste europeu, a África do Sul, entre outros. ${ }^{1}$ Já no caso da teoria do direito, é possível elencar uma série de autores, espanhóis e italianos principalmente, que procuram enquadrar a produção intelectual sobre o direito a partir do segundo pós-guerra como neoconstitucionalismo, para se referir a um modelo de direito que já não professa mais as mesmas perspectivas sobre a fundamentação do direito, sobre sua interpretação e sua aplicação, no modo como eram pensadas no contexto do primeiro constitucionalismo e do positivismo predominante até então. Assim, jusfilósofos como Ronald Dworkin e Robert Alexy (entre outros) representariam, na sua melhor luz, a grande viragem teórica operada pelo neoconstitucionalismo.

Minha obra, neste contexto, por vezes se aproximava dessa leitura sobre os movimentos que marcaram o direito no segundo pós-guerra, porém, sempre marcada por uma profunda diferença: o modo como se pensava e se procurava dar soluções para o problema da interpretação do direito. No meu caso, minha filiação às filosofias que redescobriram a hermenêutica ainda na primeira metade do século XX (no caso, a fenomenologia hermenêutica e a hermenêutica filosófica) sempre me colocou à margem de algumas das principais conclusões apuradas pela grande maioria dos teóricos do neoconstitucionalismo. Isso porque nunca consegui concordar com o modo de encarar a relação entre direito e moral ou o problema da interpretação e da aplicação do direito nos termos propostos pelo neoconstitucionalismo. Assim, se em um primeiro momento houve uma aproximação entre a minha proposta teórica e o neconstitucionalismo, isso se deu muito mais por uma questão nominal do que propriamente real.

Explico: em nenhum momento me filiei aos postulados teóricos provenientes da teoria da argumentação, que vêem uma relação de complementariedade entre o direito e a moral. Tampouco fui partidário da fórmula/regra da ponderação como modelo privilegiado de realização do direito através dos princípios. Na verdade, em minhas pesquisas, sempre desenvolvi uma atividade crítica em relação a ambos os fatores.

\footnotetext{
1 Por todos, conferir: HIRSCHL, Ran. O novo constitucionalismo e a judicialização da política pura no mundo. Revista de Direito Administrativo, n. 251, maio/agosto de 2009, pp. 139-175.
} 
Também nunca pude concordar com aquelas propostas neoconstitucionalistas que procuravam desenvolver uma versão mais analítica do fenômeno jurídico, uma vez que minha filiação à hermenêutica me atirava inexoravelmente no chão da história e da necessidade de dar conta da tradição sobre a qual repousa o fenômeno jurídico (algo que passa ao largo das preocupações de uma teoria de matriz analítica). Assim, no contexto do que pode ser entendido por neoconstitucionalismo, minhas ideias sempre representaram muito mais uma atitude de crítica do que de associação ou defesa de seus postulados.

Nesse sentido, torna-se necessário afirmar que a adoção do nomen juris "neoconstitucionalismo" certamente é motivo de ambiguidades teóricas e até de mal-entendidos. Reconheço, porém, que, em um primeiro momento, foi de importância estratégica a importação do termo e de algumas das propostas trabalhadas pelos autores da Europa Ibérica. Isto porque o Brasil ingressou tardiamente nesse "novo mundo constitucional", fator que, aliás, é similar à realidade europeia, que, antes da segunda metade do século XX, não conhecia o conceito de constituição normativa já consideravelmente decantada no ambiente constitucional estadunidense. Portanto, falar de neoconstitucionalismo implicava ir além de um constitucionalismo de feições liberais - que, no Brasil, sempre foi um simulacro em anos intercalados por regimes autoritários - em direção a um constitucionalismo compromissório, de feições dirigentes, que possibilitasse, em todos os níveis, a efetivação de um regime democrático em terrae brasilis.

Destarte, passadas mais de duas décadas da Constituição de 1988, e levando em conta as especificidades do direito brasileiro, é necessário reconhecer que as características desse neoconstitucionalismo acabaram por provocar condições patológicas, que, em nosso contexto atual, acabam por contribuir para a corrupção do próprio texto da Constituição. Ora, sob a bandeira "neoconstitucionalista", defende-se, ao mesmo tempo, um direito constitucional da efetividade; um direito assombrado pela ponderação de valores; uma concretização ad hoc da Constituição e uma pretensa constitucionalização do ordenamento a partir de jargões vazios de conteúdo e que reproduzem o prefixo neo em diversas ocasiões, tais quais: neoprocessualismo (sic) e neopositivismo (sic). Tudo porque, ao fim e ao cabo, acreditou-se ser a jurisdição responsável pela incorporação dos "verdadeiros valores" que definem o direito justo (vide, nesse sentido, as posturas decorrentes do instrumentalismo processual).

Desse modo, fica claro que o neoconstitucionalismo representa, apenas, a superação - no plano teórico-interpretativo - do paleo-juspositivismo (como bem lembra Luigi Ferrajoli), na medida em que nada mais faz do que afirmar as críticas antiformalistas deduzidas pelos partidários da escola do direito livre, da jurisprudência dos interesses e daquilo que é a versão mais contemporânea desta última, da jurisprudência dos valores.

Portanto, é possível dizer que, nos termos em que o neoconstitucionalismo vem sendo utilizado, ele representa uma clara 
contradição, isto é, se ele expressa um movimento teórico para lidar com um direito "novo" (poder-se-ia dizer, um direito "pós-Auschwitz" ou "pós-bélico", como quer Mário Losano), fica sem sentido depositar todas as esperanças de realização desse direito na loteria do protagonismo judicial (mormente levando em conta a prevalência, no campo jurídico, do paradigma epistemológico da filosofia da consciência).

Assim, reconheço, já na introdução da nova edição de Verdade $e$ Consenso, ${ }^{2}$ que não faz mais sentido continuar a fazer uso da expressão "neoconstitucionalismo" para mencionar aquilo que essa obra pretende apontar: a construção de um direito democraticamente produzido, sob o signo de uma constituição normativa e da integridade da jurisdição.

Em suma: para efeitos destas reflexões, nomearei o meu "lugar de fala" como Constitucionalismo Contemporâneo (com iniciais maiúsculas), para me referir ao movimento que desaguou nas constituições do segundo pós-guerra e que ainda está presente em nosso contexto atual, evitando os mal-entendidos que permeiam o termo neoconstitucionalismo.

\section{Esclarecendo minha posição sobre o embate "positivismo- jusnaturalismo-neoconstitucionalismo"}

Desde logo, é preciso ressaltar que, no plano da crítica ao positivismo - e, recentemente, ao próprio neoconstitucionalismo - existem posições que apresentam sensíveis divergências com relação ao meu posicionamento. Muitos dessas posições, como é o caso de Manuel Atienza, mesmo que marcando uma posição restritiva com relação a alguns postulados neoconstitucionalistas (no que estamos totalmente de acordo), partem de um ponto que considero limitado de caracterização do positivismo. Ou seja, Atienza (e falo do mestre espanhol por todos, uma vez que essa posição sobre o positivismo tem larga prevalência na teoria do direito europeia) vê o positivismo em uma perspectiva estrita ${ }^{3}$. Penso que essa posição - que considero "uma visão (r)estrita do positivismo" - está demonstrada pela redução do trabalho investigativo a elementos descritivos, livre de valores. Isso é resultado da "separação entre direito e moral" e de uma leitura da característica positivista das "fontes sociais do direito" como simples

\footnotetext{
${ }^{2}$ Cf. STRECK, Lenio Luiz. Verdade e Consenso. 4. ed. São Paulo: Saraiva, 2011.

${ }^{3}$ Como se sabe, Atienza diz que o positivismo é uma concepção empobrecida de direito, porque ela é apenas descritiva e afasta do direito todos os elementos valorativos. Claro que concordo com isso. Entretanto, o positivismo não pode ser reduzido a essa tese que considero restritiva. Cf. ATIENZA, Manuel. El sentido del derecho. Barcelona: Ariel; 2004; __. Sobre Ferrajoli y la superación del positivismo jurídico. In: FERRAJOLI, Luigi; MORESO, José Juan; ATIENZA, Manuel. La teoría del derecho en el paradigma constitucional. Madrid: Fundación Coloquio Jurídico Eoropeo, 2008; __. As razôes do direito: teorias da argumentação jurídica. 3. ed. São Paulo: Landy, 2006; _. Dos versiones del constitucionalismo. In.: Revista de Estudos Constitucionais, Hermenêutica e Teoria do Direito (RECHTD), v. 4, n. 1, janeiro-junho, p. 29-39, 2012; ; MANERO, Juan Ruiz. Sobre princípios e regras. In: Panóptica, v.4, n.3, p. 49-68, 2009.
} 
rechaço do direito natural, dando a entender que a via jusnaturalista seria - ainda - possível nesta quadra da história.

Na minha concepção, o positivismo é bem mais complexo do que isso. Isto porque tanto no primeiro quanto no segundo caso existem reducionismos que contribuem para retirar clareza da questão. No primeiro caso, há uma confusão entre a dimensão da ciência do direito e o ambiente das práticas jurídicas. Positivistas mais sofisticados - como é o caso de Kelsen - separaram a ciência jurídica da moral, mas não o nível das práticas jurídicas (ou política judiciária, nas palavras do mestre austríaco). Kelsen não separa o direito da moral e, sim, a ciência do direito da moral. Em Kelsen, o cientista do direito não deve se orientar por valores no momento de executar sua tarefa descritiva. Entretanto, os "operadores" do direito, não estão necessariamente vinculados a uma tal determinação. Podem segui-la ou não. Como acontece, aliás, com os outros campos predadores da autonomia do direito (política, psicologia, etc..). Aliás, esse o sentido da discricionariedade em sentido forte de que fala Dworkin: se, em seu ato de escolha, o agente de decisão transbordar os limites autorizados para a prática do ato, ninguém poderá censurá-lo por erro.

De outra banda, não creio que ainda hoje seja possível falar em direito natural ou jusnaturalismo. Penso que não há espaço para o jusnaturalismo nos contemporâneos paradigmas filosóficos. Vale dizer: acreditar na dicotomia jusnaturalismo-positivismo implica professar um tipo de objetivismo filosófico. Outro problema que me afasta das concepções que vêm o positivismo desse modo estrito ou restritivo é a visão que muitos jusfilósofos tem acerca de Dworkin, colocando-o como um autor jusnaturalista ou ético-cognotivista. Para mim, isso representa um equívoco. O jusfilósofo americano gastou páginas e páginas para demonstrar sua posição que afirma ser o direito um conceito interpretativo. Ora, se assim o é, como pode o direito ser interpretativo e natural ao mesmo tempo? Por certo, não pode. Aliás, existem contemporaneamente, de Castanheira Neves a Arthur Kaufmann, posições teóricas que procuram posicionar-se criticamente diante dessa vetusta dicotomia positivismo vs. jusnaturalismo.

Dito de outro modo, o problema das fontes sociais do direito, para além da questão de rechaço do jusnaturalismo, está na necessidade de ancorar a produção normativa do direito em uma autoridade social visível e constituída. Esse é um dos principais pontos da critica de Dworkin a Herbert Hart. Critica absolutamente correta, diga-se de passagem. Afinal, quem deu origem aos princípios? Para Dworkin, a história institucional de uma comunidade política. Falando com todas as letras e com a maior clareza possível: isso não representa um retorno ao jusnaturalismo... História institucional não pode ser algo natural. Pelo simples fato de ser história.

Ao fim e ao cabo, é importante ainda anotar o seguinte: em minhas obras venho discutindo há muito tempo a necessidade de superação do positivismo normativista e do neoconstitucionalismo, já que ambos, dentro de suas 
especificidades, acabam por cair no velho problema da discricionariedade judicial (que, para mim, é a principal característica do positivismo). Assim, é importante destacar que, quando trato do paradigma positivista, não estou fazendo referência ao exegetismo ou ao conceptualismo pandectista - escolas pertencentes ao positivismo primitivo -, mas ao positivismo kelseniano, que, no caso, é responsável por deixar para o órgão aplicado da norma a capacidade de se manifestar de forma voluntarista, já que para este a interpretação - no nível das práticas jurídicas - sempre acaba reduzida a um ato de vontade. Não que isso seja assim porque Kelsen acredite que a discricionariedade seja algo legítimo ou necessariamente bom. Mas, sim, porque o mestre austríaco rendeu-se aos dilemas da semântica e - fatalisticamente - abandonou o nível poluído do ambiente propriamente interpretativo do direito pela pureza da ciência. É por isso que Friedrich Müller afirma que o normativismo kelseniano não pode dar nenhum tipo de contribuição para uma teoria da interpretação ${ }^{4}$.

Por isso, ao contrário do que alguns autores pretendem apresentar como "constitucionalismo pós-positivista", por meio de um resgate do "aspecto valorativo do direito" para a superação do positivismo primitivo, eu denomino pós-positivismo a superação do positivismo normativista (e também do positivismo fático exsurgido das posturas do realismo jurídico) e da discricionariedade, por meio de uma necessária teoria da decisão, que efetivamente dê conta do problema interpretativo do direito. Por outro lado, é preciso consignar que em diversas correntes o neoconstitucionalismo tem flertado com a ponderação e, ao mesmo tempo, com a retomada dos valores pelo direito, por meio de teses "principiológicas". Alguns críticos do neoconstitucionalismo atacam este posicionamento afirmando que entre a ponderação e a subsunção não existe incompatibilidade, sendo que em cada caso concreto poderá ser utilizado um ou outro modelo argumentativo; já com relação ao "principiologismo", os mesmos críticos têm apontado suas baterias para a predominância excessiva dos princípios sobre as regras.

Diferentemente deles, minha crítica ao neoconstitucionalismo tem atacado constantemente o uso da ponderação, a recepção da jurisprudência dos valores e o entendimento equivocado sobre os princípios, ao considerar que estas posições promovem a discricionariedade judicial, já que em todas elas acabam por abandonar o problema interpretativo à vontade - decisionista - do aplicador de normas, enfraquecendo demasiadamente a legalidade constitucional. Ou seja, para mim tanto são positivistas as posturas clássicas (separação do direito da moral), como também as que apelam à discricionariedade. Na medida em que os diversos neoconstitucionalismos não abrem mão da discricionariedade e fazem firme aposta na ponderação, minha posição é de que são (também) positivistas. Não primitivos ou clássicos; mas positivistas pós-exegéticos.

\footnotetext{
${ }^{4}$ Cf. MÜLLER, Friedrich. O Novo Paradigma do Direito. São Paulo: Revista dos Tribunais, 2006, passim.
} 


\section{Buscando esclarecer "a questão do positivismo"}

A partir de campos diferentes do conhecimento, é possível, já de pronto, separar o velho e o novo no direito. Em outras palavras, se não há segurança para apontar as características de uma teoria efetivamente pós-positivista e neoconstitucional, há, entretanto, condições para que se possa dizer "o que não é" e "o que não serve" para a contemporânea teoria do direito, mormente em países com sistemas e ordenamentos jurídicos complexos.

Mas, o que a hermenêutica - na leitura que proponho a partir de Verdade e Consenso e Hermenêutica Jurídica $e(m)$ Crise, imbricando Gadamer e Dworkin - pode contribuir para a compreensão desse novo constitucionalismo? Quais os pontos de encontro entre as análises hermenêuticas e aquelas advindas do terreno da(s) teoria(s) da argumentação? Ou, do mesmo modo, qual é a ligação entre a hermenêutica e as teorias discursivas compreendidas lato sensu?

Diferenças à parte - e sobre essas falarei mais adiante -, uma coisa é certa: sob o novo paradigma constitucional (do segundo pós-guerra), o mundo prático passou a importar os juristas. $O$ direito já não seria mais o mesmo. $O$ direito já não poderia mais ser epitetado e/ou acusado de ser uma "mera racionalidade instrumental" ou um instrumento destinado à proteção dos interesses das classes dominantes, resultado das duas fases do legalismo, do nascedouro da modernidade ao direito contemporâneo. As questões morais, políticas e econômicas - rejeitadas pelo positivismo jurídico - passaram a fazer parte da preocupação da comunidade jurídica.

Lembremos que, historicamente, as teorias positivistas do direito recusaram-se a fundar suas epistemologias numa racionalidade que desse conta do agir propriamente dito (escolhas, justificações, etc). Como alternativa, estabeleceram um princípio fundado em uma razão teórica pura: o direito, a partir de então, deveria ser visto como um objeto que seria analisado segundo critérios emanados de uma lógica formal rígida. E esse "objeto" seria produto do próprio sujeito do conhecimento. Daí o papel do sujeito solipsista (Selbstsüchtiger).

Para o positivismo jurídico (clássico), pouco importava colocar em discussão - no campo d(e um)a teoria do direito - questões relativas à legitimidade da decisão tomada nos diversos níveis do poder estatal (Legislativo, Executivo ou Judicial). No fundo, operou-se uma cisão entre validade $e$ legitimidade, sendo que as questões de validade seriam resolvidas através de uma análise lógico-semântica dos enunciados jurídicos, ${ }^{6}$ ao passo que os problemas de legitimidade - que incluem uma problemática moral - deveriam ficar sob os cuidados de uma teoria política que poucos resultados poderiam produzir, visto que esbarravam no problema do pluralismo de ideias presente

\footnotetext{
${ }^{5}$ Cf. STRECK, Lenio Luiz. Hermenêutica Jurídica e(m) crise. 11. ed. Porto Alegre: Livraria do Advogado, 2011; Verdade e Consenso, op.cit.

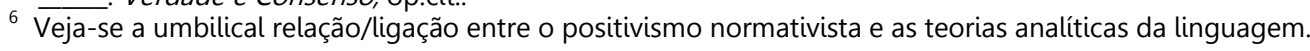


num contexto democrático, o que levava, inexoravelmente, a um relativismo filosófico (essa problemática se gravou em países com grandes períodos de ausência de democracia, como o Brasil).

Por certo, a pretensão das teorias positivistas era oferecer à comunidade jurídica um objeto e um método seguro para produção do conhecimento científico no direito. Isso levou - de acordo com a atmosfera intelectual da época (problemática que, entretanto, ainda não está superada) - a uma aposta em uma racionalidade teórica asfixiante que isolava/insulava todo contexto prático de onde as questões jurídicas realmente haviam emergido. Melhor dizendo, essa racionalidade teórica possibilitou - e continua a possibilitar - a "entender" o direito em sua "autônoma objetividade". Repetindo o que já foi dito anteriormente: os fatos sociais, os conflitos, enfim, a faticidade, não faziam parte das "preocupações" da teoria do direito. Portanto, ironicamente, a pretensão estabilizadora e cientificizante do positivismo jurídico acabou por criar uma babel resultante da separação produzida entre questões teóricas e questões práticas, entre validade e legitimidade, entre teoria do direito e teoria política.

De todo modo, vale a pena insistir nos pontos de convergência das teorias autodenominadas neoconstitucionalistas e as demais teorias críticas (de cariz pós-positivista): diante dos fracassos do positivismo tradicional, a partir da busca da construção de uma autônoma razão teórica, as diversas posturas críticas buscaram, sob os mais diversos âmbitos, (re)introduzir os "valores" no direito. Assim, por exemplo, diante de uma demanda por uma tutela que esteja relacionada com a vida, com a dignidade da pessoa, enfim, com a proteção dos direitos fundamentais, o que fazer? Qual é a tarefa do jurista?

Na medida em que existem vários neoconstitucionalismos, uma coisa é possível dizer: mesmo que muitas das concepções neoconstitucionalistas tenha resvalado para o voluntarismo, elas não trouxeram a indiferença. Sem exclusões, para elas há uma preocupação de ordem ético-filosófica: a de que o direito deve se ocupar com a construção de uma sociedade justa e solidária. Em outras palavras, o desafio tem sido o seguinte: como fazer com que o direito não fique indiferente às injustiças sociais? Como superar o positivismo exegético (embora para as posturas neoconstitucionalistas o positivismo seja entendido lato sensu a partir do conceito clássico)? Como fazer com que a perspectiva moral de uma sociedade que aposte no direito como o lugar da institucionalização do ideal da vida boa não venha pretender, em um segundo, "corrigir" a sua própria condição de possibilidade, que é o direito que sustenta o Estado Democrático?

Vejamos isso. Parece que para Oto e Pozzolo, assim como Carbonell e Prieto Sanchis, para falar apenas destes, não parece haver dúvida de que "neoconstitucionalismo" é sinônimo de "novo paradigma". O direito deixa de ser meramente regulador para assumir uma feição de transformação das relações sociais, circunstância que pode ser facilmente constatada a partir do exame dos textos constitucionais surgidos a partir do segundo pós-guerra. Com a desconfiança em relação ao legislativo (e às mutações produzidas pelas maiorias 
incontroláveis), passou-se a apostar em uma matriz de sentido dotada de garantias contra essas maiorias eventuais (ou não). Isso implicou - e continua a implicar - mudanças de compreensão: como olhar o novo com os olhos do novo, sem correr o risco de transformar o novo no velho? Esse passou a ser o grande desafio da teoria do direito.

Aliás, é Écio Oto quem indaga, na esteira de Prieto Sanchís: em que medida o constitucionalismo ou o juízo de constitucionalidade obriga a uma importante revisão da teoria do direito e, dado que nossa teoria do direito é basicamente uma construção positivista, a questão consiste em determinar até que ponto este último ficou obsoleto? Por isso, desde logo tenho que indagar: se as posturas neoconstitucionalistas não abrem mão da discricionariedade judicial, por que razão pode(ria)m ser consideradas pós-positivistas?

De todo modo, é possível dizer que Pozzolo, Oto e Sanchís - e tantos outros - efetivamente se perguntam acerca da questão que é fulcral na discussão: quais as condições de possibilidade que tem a teoria do direito para atender às "demandas" de um novo paradigma que, primordialmente, tem a função de superar as insuficiências das teorias positivistas?

\section{4 - As ditas características do neoconstitucionalismo}

Quais seriam os elementos caracterizadores desse movimento neoconstitucionalista? Seria uma espécie de positivismo sofisticado? O neoconstitucionalismo teria características de continuidade e não de ruptura? Não há suficiente clareza nas diversas teses acerca do significado do neoconstitucionalismo. ${ }^{7}$ Mas isso não constitui um problema. Ao contrário, possibilita a abertura para a reflexão. Alguns importantes juristas ${ }^{8}$ procuram seguindo uma antiga classificação de Norberto Bobbio para o positivismo classificá-lo em neoconstitucionalismo ideológico, teórico ou metodológico. Penso, entretanto, que, exatamente pela perspectiva ruptural que assume e porque a questão é paradigmática, essa classificação não assume relevância, pelo menos para os limites de minhas reflexões.

\footnotetext{
7 Aqui vale lembrar, como destaquei inicialmente, que essa heterogeneidade que permeia o chamado neoconstitucionalismo acaba por gerar sérios problemas com relação ao uso (e o abuso, em alguns casos) dessa nomenclatura. Por essa razão, e na tentativa de tornar ainda mais clara a minha posição teórica, optei por chamar de Constitucionalismo Contemporâneo o meu lugar de fala. Portanto, quando falo aqui de neoconstitucionalismo refiro-me às posições teóricas que, de alguma forma, estão escoradas no constitucionalismo do segundo pós-guerra; propõem uma atitude crítica perante o positivismo, mas que, ao fim e ao cabo, acabam por professar teses similares ao positivismo normativista. Ou seja, representam, quando muito, uma superação do positivismo exegético-conceitual-primitivo, mas, não efetuam um salto qualitativo com relação à revisão do positivismo efetuada pelos teóricos normativistas. Refiro-me aqui, principalmente, ao ab-uso do termo no Brasil, onde o neoconstitucionalismo tem servido para incentivar, nos diversos ramos do direito, protagonismos judiciais.

${ }^{8}$ Essa classificação é feita por COMANDUCCI, Paolo. Formas de (neo)constitucionalismo. Un análises metateórico. In: CARBONELL, Miguel (Org.). Neoconstitucionalismo(s). Madrid: Trotta, 2003.
} 
Com efeito - mesmo que se admita essa tricotomia -, a um só tempo, o neoconstitucionalismo é ideológico, porque alça a Constituição a "elo conteudístico" que liga a política e o direito (aqui se poderia falar no aspecto compromissório e dirigente da Constituição, que é, assim, mais do que norma com força cogente: representa uma justificação político-ideológica); é teórico, porque estabelece as condições de possibilidade da leitura (descrição) do modelo de constitucionalismo e dos mecanismos para superação do positivismo (papel dos princípios como resgate do mundo prático expungido do direito pelo positivismo, problemática que deve ser resolvida a partir dessa teoria do direito e do Estado); e é também metodológico, porque ultrapassa a distinção positivista entre descrever e prescrever o direito, sendo que, para tal, reconecta direito e moral (que ocorre sob vários modos, a partir de teses como a cooriginariedade entre direito e moral ou o papel corretivo que a moral assumiria neste novo modelo de direito).

O neoconstitucionalismo efetivamente vem gerando controvérsias. Tem sido teorizado sob os mais diferentes enfoques. Écio Oto, de forma percuciente, faz uma descrição das principais propriedades/características desse fenômeno. Essa "planta" do neoconstitucioonalismo possui a assinatura de autores do porte do próprio Écio Oto, Susanna Pozzolo, Prieto Sanchís, Sastre Ariza, Paolo Comanducci, Ricardo Guastini, com variações próprias decorrentes das matrizes teóricas que cada um segue..$^{9}$ A elas procuro fazer uma análise, na sequência. Com efeito:

Primeira característica - Pragmatismo: de plano, há que se reconhecer que existe certa "anemia significativa" na expressão "pragmatismo". Com efeito, pragmatismo pode ser entendido - na teoria do direito contemporânea - como "quase sinônimo" de realismo e axiologismo. O pragmatismo e suas variantes guardam estreita relação com a sua origem "pragmaticista" de Peirce, isto é, uma "filosofia sem fundamentos ontológicos a prior". Mas sua origem é anterior, na medida em que vem do termo grego "pragma", que quer dizer uma ocorrência, um fato concreto, em particular algo prático, com efeitos relevantes. As primeiras manifestações pramati(ci)stas no direito podem ser encontradas no realismo escandinavo (Alf Ross, Olivecrona) e norte-americano (Wendell, Pound e

\footnotetext{
9 Além da obra de Écio Oto Ramos Duarte e Susanna Pozzolo, há importantes discussões acerca da caracterização do neoconstitucionalismo brasileiro. Vejam-se as contundentes críticas que Dimitri Dimoulis faz às três características defendidas por Luis Roberto Barroso (reconhecimento da força normativa da Constituição, expansão da jurisdição constitucional e nova interpretação constitucional). Para Dimitri, o elemento peculiar - para ele, o único - do que se vem denominando de neoconstitucionalismo estaria "na crença de que a moral desempenha um papel fundamental na definição e na interpretação do direito". (Cf. Neoconstitucionalismo e moralismo jurídico. In: SARMENTO, Daniel (Org.). Filosofia e Teoria Constitucional Contemporânea. Rio de Janeiro: Lumen Juris, 2009, pp. 213-225). Outro trabalho de fôlego é feito por Daniel Sarmento (O neoconstitucionalismo no Brasil. In: LEITE, George Salomão; SARLET, Ingo. Wolfgang (Coord). Direitos Fundamentais e Estado Constitucional: estudos em homenagem a J.J. Gomes Canotilho. São Paulo: RT, 2008, pp. 9-49), em que faz uma defesa do neoconstitucionalismo, entendendo este como uma teoria voltada para os princípios e para o uso da ponderação, além da firme atuação da justiça constitucional para a defesa dos valores e da conectividade do direito com a moralidade crítica. Em Sarmento, nota-se nitidamente que o neoconstitucionalismo está umbilicalmente ligado à defesa do poder discricionário dos juízes e do uso da ponderação.
} 
Cardozo), daí a "semelhança" entre as duas posturas sobre o direito (realismo jurídico e pragmatismo).

Contemporaneamente, o pragmatismo pode ser identificado sob vários matizes, como a análise econômica do direito, de Richard Posner, os Critical Legal Studies e as diversas posturas que colocam na subjetividade do juiz o locus de tensão da legitimidade do direito (protagonismo judicial). O pragmatismo pode ser considerado como uma teoria ou postura que aposta em um constante "estado de exceção hermenêutico" para o direito; o juiz é o protagonista, que "resolverá" os casos a partir de raciocínios e argumentos finalísticos. Trata-se, pois, de uma tese anti-hermenêutica e que coloca em segundo plano a produção democrática do direito.

Assim, ao se pretender colocar o neoconstitucionalismo como superador do positivismo (mormente no que tange à teoria das fontes, da relação entre direito e moral - que implica a distinção "regra-princípio" - e o problema da discricionariedade), sua filiação ao pragmatismo pode representar um problema, a partir da ideia de "grau zero de sentido" e de um certo "nominalismo" - ínsitos ao pragmatismo que propicia discricionariedades e/ou arbitrariedades interpretativas. E "grau zero" é sinônimo de decisionismo, de discricionarismo. E discricionarismo é característica do positivismo. Mas, então, tem-se uma contradição: ao apostar no pragmatismo, não parece haver superação do positivismo. Consequentemente, se o neoconstitucionalismo se pretende póspositivista, não pode ser pragmati(ci)sta. Mas isso parece impossível.

Segunda característica - Ecletismo (sincretismo) metodológico: efetivamente, um dos traços mais marcantes do neoconstitucionalismo é o ecletismo metodológico. De fato, entendendo a metodologia como teoria do direito, corre-se o risco de comprometer o resultado aplicativo do direito toda a vez que se lançar mão de "mixagens" de matrizes teóricas incompatíveis. Essa questão fica mais nítida quando confrontamos, por exemplo, a hermenêutica filosófica com as teorias da argumentação, para ficar apenas nesse "confronto": enquanto aquela tem a pré-compreensão (antecipação de sentido) como condição de possibilidade, esta fica no plano da explicitação lógicoprocedimental. Além disso, enquanto a hermenêutica, calcada na tradição, aposta em um antirrelativismo, as teorias da argumentação não abrem mão da discricionariedade, o que denuncia seu atrelamento ao esquema sujeito-objeto. ${ }^{10}$ Finalmente, não se pode olvidar a indevida mixagem feita por determinados autores neconstitucionalistas das posições de Ronald Dworkin e Robert Alexy ${ }^{11}$;

\footnotetext{
10 Sobre esse ponto específico das críticas às teorias da argumentação, permito-me remeter o leitor especialmente ao meu Verdade e Consenso, op.cit.

${ }^{11}$ No que tange, especificamente, a essa mixagem entre as posturas de Dworkin e Alexy, é possível mencionar MORESO, José Juan. Conflito entre Princípios Constitucionales. In: Neoconstitucionalismo(s). Madrid: Trotta, pp. 99-121.
} 
ou das teorias habermasianas e alexianas, ${ }^{12}$ que agregam ao proceduralismo de Habermas a ponderação de Alexy.

Mas, veja-se: o sincretismo não se mostra adequado a uma teoria que predente superar o(s) positivismos. Na verdade, os sincretismos são (ou foram) um fator de enfraquecimento do neoconstitucionalismo (embora Oto queira coloca-lo como virtude). Se em algum momento o neoconstitucionalismo vizava a ir além do positivismo normativista ou congêneres, na medida em que a superação do paleojuspositivismo sempre pareceu evidente, a falta de uma coerência teorética o fragilizou sobremodo.

Terceira característica - Principialismo: essa característica seria o lócus da junção entre direito e moral no neoconstitucionalismo. Princípios seriam, assim, "pautas axiológicas" ou "mandados de otimização", representando a assunção dos "valores" aos textos constitucionais. A Constituição seria uma "ordem suprapositiva de valores", conforme expressão cunhada pelo Bundesverfassungsgericht (Tribunal Constitucional alemão) no auge de sua prática de "jurisprudência dos valores" (Wertungsjurisprudenz). Assim, não parece haver qualquer dúvida de que o principialismo é elemento caracterizador do neoconstitucionalismo. A questão é saber o que se entende por "princípio" e qual é o seu papel na aplicação do direito. ${ }^{13}$ Ou seja, aqui também vai a pergunta: essa característica também estaria posta como uma virtude do neoconstitucionalismo?

Ora, que os diversos positivismos eram avessos aos princípios, também parece não haver dúvidas. Efetivamente, o neoconstitucionalismo (no modo defendido por autores como Prieto Sanchis, Écio Oto, Susanna Pozzolo) está fundado no principialismo como modo de fazer ingressar "os valores para dentro do direito" (aqui reside um ponto de minha forte discordância com o neoconstitucionalismo, uma vez que os "valores" fragilizam o grau de autonomia alcançado pelo direito; como venho referindo de há muito, os princípios introduzem o mundo prático - no sentido filosófico da expressão - no direito).

Visto desse modo, é correto colocar o principialismo como característica do neoconstitucionalismo. A ressalva que se põe diz respeito ao risco de uma expansão desmesurada de princípios, acarretando uma espécie de pamprincipiologismo, o que enfraquece sobremodo o grau de autonomia que o direito alcançou justamente no seio do constitucionalismo exsurgido a partir do segundo pós-guerra.

12 Por todos, vale referir, no Brasil, Rogério GESTA LEAL (O Estado-Juiz na democracia contemporânea: uma perspectiva procedimentalista. Porto Alegre: Livraria do Advogado, 2007) e Antonio MAIA (A distinção entre fatos e valores e as prelensões neofrankfurtianas. In: Perspectivas atuais da filosofia do direito. Rio de Janeiro: Lumen Juris, 2005).

${ }^{13}$ Nesse sentido, a obra de Rafael TOMÁZ DE OLIVEIRA vai além das teses tradicionais que povoam o discurso panprincipiologista ao procurar elucidar um conceito de princípio hermeneuticamente adequado (Cf. Decisão Judicial e o Conceito de Princípio. a hermenêutica e a (in)determinação do Direito. Porto Alegre: Livraria do Advogado, 2008). 
Como venho insistindo: se princípios são normas e, portanto, possuem um caráter deontológico, deve haver um cuidado com a transformação destes em uma espécie de "instância corretiva do direito produzido democraticamente". Antes de os princípios serem a porta de entrada dos "valores"14 - esquecidos pelo positivismo - nos textos constitucionais, são eles a porta de entrada do mundo prático no direito como um todo, fazendo com que se supere a ideia de uma razão teórica com pretensões autônomas, característica do positivismo jurídico.

Podemos dizer que isso tudo funciona da seguinte forma: quando nos ocupamos com questões jurídicas, possuímos, antecipadamente/précompreensivamente, um todo conjuntural que nos permite articular os diversos instrumentos que a tradição jurídica construiu. Há sempre um todo antecipado em cada ato particular que praticamos como advogados, procuradores, promotores, juízes etc. No contexto da tradição em que estamos inseridos, este todo é representado pela Constituição. Mas não a Constituição enquanto um texto composto de diversas fatias: artigos, incisos, alíneas etc., mas, sim, a Constituição entendida como um evento que introduz, prospectivamente, um novo modelo de sociedade.

Este evento que é a Constituição está edificado sob certos pressupostos que chegam até nós pela história institucional de nossa comunidade. Tais pressupostos condicionam toda tarefa concretizadora da norma, porque é a partir deles que podemos dizer se o direito que se produz concretamente está legitimado de acordo com uma tradição histórica que decidiu constituir uma sociedade democrática, livre, justa e solidária.

Este todo conjuntural, portanto, irá determinar os juízos concretos e particulares que fazemos para solucionar os problemas jurídicos. Neste sentido, por mais que essa conjuntura não apareça de modo explícito no trabalho de fundamentação que todo jurista deve realizar, ela condiciona os argumentos alinhavados na decisão de modo subterrâneo.

Para ser mais claro: não há causa judicial, não há caso concreto em que não exista uma discussão - ainda que encoberta - sobre a igualdade, por exemplo. Ora, sempre no direito lidamos com alguma situação discriminatória. A concessão de uma liminar, por exemplo, já é por si só o exercício de um tratamento diferenciado dado a alguém que faz jus a determinados requisitos de ordem formal. Porém, na concessão desta liminar, o juiz que profere a decisão estará obrigado a justificar o porquê do tratamento diferenciado dado àquele que requer a medida antecipatória. Do mesmo modo que haverá de justificar no caso de negação do pedido. Uma liminar negada para alguém será a concessão/manutenção de um direito em favor de outrem. Assim também ocorre com aquilo que conhecemos por devido processo legal. Não pode haver

\footnotetext{
${ }^{14}$ Veja-se: o grande problema da jurisprudência dos valores tem sido exatamente esse "conceito" líquido de "valores". Qual seria a diferença dos "valores" propugnados pela Wertungsjurisprudenz daqueles "valores" defendidos pelo neoconstitucionalismo? Tratar-se-ia, em ambos os casos, de um "realismo moral"?
} 
processo que não tenha se desenvolvido no contexto de seu âmbito de aplicação.

É por isso que, neste sentido, não se pode falar em "abertura" interpretativa $^{15}$ no que tange aos princípios jurídicos: nos dois casos analisados parece ficar claro que eles condicionam o intérprete no sentido de obrigá-lo a decidir de modo a não comprometer o todo conjuntural da comum-unidade dos princípios constitucionais.

Mas, então, é necessário perguntar, como fica a distinção que se realiza entre regras e princípios? É válida tal distinção? É essa distinção uma distinção lógica-estrutural, epistemológica, ou nela se esconde algo mais que a simples determinação do objeto a ser conhecido?

A (tradicional) distinção estrutural oferece uma resposta sistemática, mas não resolve a questão da concretização propriamente dita. Isto porque deita raízes na velha questão presente a partir do neopositivismo lógico e sua superação pela filosofia da linguagem ordinária. A circunstância agravante - que corre em prejuízo à teoria da argumentação que amadrinha a distinção lógicoestrutural entre regra e princípío - reside na relevante circunstância de que a filosofia da linguagem ordinária apostou na pragmática como um salto para além da plenipotenciariedade das análises sintáticas e semânticas (lembremos que, para o neopositivismo lógico, somente eram científicos os enunciados que passassem pelo filtro da sintaxe e da semântica, desconsiderando totalmente a pragmática), ao passo que as teorias da argumentação apostam, ao mesmo tempo, nas concepções neopositivistas e da filosofia da linguagem ordinária.

Ou seja, as teorias da argumentação, nos casos simples, contentam-se com as análises sintático-semânticas (é o caso da subsunção); já quando estão em face de um caso difícil, apelam para a pragmática. Mas somente apelam para esse nível quando o primeiro não responde às demandas significativas. Ora, a filosofia da linguagem ordinária, ao se dar conta das demandas resultantes desse terceiro nível da semiótica (relação dos usuários com os signos), considerou como estando superado o neopositivismo, exatamente porque este se contentava com os dois primeiros níveis (sintático e semântico). Isso é de uma clareza meridiana. Já a teoria da argumentação jurídica trabalha, ao mesmo tempo, com as concepções neopositivistas pragmati(ci)stas (filosofia da linguagem ordinária), porém faz isso desconsiderando que o neopositivismo não realizava a análise semântica no mesmo nível da linguagem objeto. Isto é, para o neopositivismo, haveria a necessidade de uma metalinguagem para certificação dos resultados das contradições lógicas da linguagem objeto.

O problema é que, ao ser feita a distinção estrutural (que ocorre no nível semântico), os princípios acabam adquirindo algo que lhes tira a "razão principiológica", isto é, alça-se-lhes a meta-regras, o que faz com que, no fundo,

\footnotetext{
${ }^{15}$ Os princípios não abrem a interpretação e, sim, fecham-na. Nesse sentido, ver meu Verdade e Consenso, op.cit., em especial o capítulo 13.
} 
o princípio apenas ingresse no sistema para "revolver insuficiências ônticas" das regras, como ocorre, por exemplo, com a teoria da argumentação jurídica. Só para recordar: como é sabido, para teoria da argumentação jurídica, o problema das regras se resolve por subsunção e o dos princípios pela ponderação (embora esta se "concretize" como uma regra, que também será aplicada por subsunção). Isso também se aplica à diferença entre axiologia e deontologia, e é por isso que - e me permito insistir neste ponto - princípios não são valores. Para que um princípio tenha obrigatoriedade, ele não pode se desvencilhar da democracia que se dá por enunciados jurídicos concebidos como regras.

Quarta característica - Judicialismo ético-jurídico: por esse elemento caracterizador, o neoconstitucionalismo exigiria dos operadores jurídicos cada vez mais a elaboração de juízos de adequação e juízos de justificação com natureza ética, ao lado das técnicas estritamente subsuntivo-jurídicas. Não se pode discordar dessa "demanda" proveniente do novo paradigma. Com efeito, na medida em que diminui o grau de liberdade de conformação do legislador (essa era uma característica do positivismo), há um deslocamento do polo de tensão em direção ao Poder Judiciário (ou da judicialização, questão que assume grau de dramaticidade em países como o Brasil - provavelmente, não há país no mundo com um grau de judicialiação como o de terrae brasilis). Consequentemente, "aumenta o poder dos juízes e dos tribunais". Os juízes não são mais a "boca da lei", como se costuma dizer nas diversas posturas críticas que surgem a partir do segundo pós-guerra e, no Brasil, a partir da Constituição de 1988. Veja-se, nesse sentido, a decisão, em sede liminar, proferida pelo Min. Roberto Barroso, no MS 32326, em que, explicutamente, fez menção ao uso de argumentos-fundamentos metajuridicos e apelo à moral.

Ou seja, esse "aumento de tensão" em favor da jurisdição pode acarretar problemas na democracia. $E$ isso não tem sido muito bem pensado por alguns adeptos do neoconstitucionalismo, ao confundirem a exigência de um direito "moralizado" com a "moralização do direito", na medida em que esta - a moral é utilizada de forma "corretiva" (confessadamente ou não, já que, na maior parte das vezes, a moral "corretiva" entra pela porta dos fundos do direito, por intermédio de um pamprincipiologismo ou "diretamente" via ativismo judicial, com o livre exercício da "discricionariedade") ${ }^{16}$.

Por isso, mais do que suscitar um "judicialismo ético-jurídico", há que se indagar acerca das condições de possibilidade que temos para controlar (racionalizar) as decisões judiciais. Neste ponto a teoria do direito deve fazer uma opção: admitir discricionariedades judiciais ou não. Se se conferir aos juízes um

\footnotetext{
${ }^{16}$ Veja-se como, nesses casos, aquilo que se quer chamar de "neoconstitucioonalismo" nada mais é do que o velho positivismo aplicado a partir da discricionariedade forte (que se transforma, fatalmente, em "arbitrariedade). Aquilo que aparece como "julgamento conforme a consciência" (sic) do juízes acaba sendo a mais "pura" substituição da produção democrática do direito (inclusive da Constituição) pelos juízos morais do intérprete/julgador.
} 
poder discricionário, estar-se-á fazendo um retrocesso em direção ao positivismo.

Por tais razões, há que se fazer uma diferenciação entre judicialismo (ou judicialização) e ativismo: o primeiro decorre das contingências de um paradigma; o segundo pode ser destrutivo, uma vez que permite substituir os juízos morais e políticos institucionalizados no direito produzido democraticamente pela opção "pessoal" dos juízes. Por isso é que insisto na questão de que o problema do positivismo e sua superação está umbilicalmente ligado à derrocada do sujeito da modernidade: o Selbstsüchtiger. Numa palavra: o judicialismo é uma característica do neoconstitucionalismo; e isso também é um dos seus maiores defeitos.

Quinta Característica - Interpretativismo moral-constitucional: esta característica representaria uma espécie de "imperialismo da moral", nas palavras críticas de Mauro Barberis ${ }^{17}$, debitando à teoria dworkiniana da leitura moral da Constituição esse traço distintivo do neoconstitucionalismo. Penso, entretanto, que essa "ineludível" intervenção dos "juízos de valor" - a expressão é de Écio Oto - constitui um problema apenas se considerarmos a discricionariedade como um componente ineludivel do neoconstitucionalismo. Dworkin, por exemplo, é inimigo figadal do poder discricionário.

Dito de outro modo, se pensarmos que a discricionariedade é um problema e não uma solução, o assim denominado "interpretativismo moral" passa ao largo dessa discussão, uma vez que essa parece não ser - como, de fato, não é - a tese defendida por Dworkin. Nesse sentido, e uma vez mais visando a evitar mal-entendidos, é preciso compreender que - do mesmo modo que Gadamer, em seu Wahrheit und Method - Dworkin não defende qualquer forma de solipsismo (a resposta correta que ele sustenta não é produto da atitude de um Selbstsüchtiger). Tenho que Dworkin superou - e de forma decisiva - a filosofia da consciência (e as suas vulgatas voluntaristas). E a discricionariedade é produto do paradigma do voluntarismo. Melhor dizendo, o juiz "Hércules" é apenas uma metáfora para demonstrar que a superação do voluntarismo. Ou seja, a morte do sujeito solipsista da modernidade não significou a morte do sujeito que sempre está presente em qualquer relação de objeto. Na verdade, há uma falsa impressão de que Hércules representa o portador de uma "subjetividade assujeitadora", problemática que expolico amiúde em Hermenêutica Jurídica e(m) Crise.

Haverá um interpretativismo moral e, com isso, uma fragilização de qualquer teoria que se pretenda "neoconstitucional" se, a uma, considerarmos que os juízos morais possam vir a corrigir o direito produzido democraticamente, o que, por sua vez, implica a admissão da discricionariedade, problemática que

${ }^{17}$ Cf. BARBERIS, Mauro. Neoconstitucionalismo, democracia y imperialismo de la moral. In: CARBONELL, Miguel (Org.), Neoconstitucionalismos. Madrid: Trota, 2003, p. 270. 
está presente, por exemplo, em Alexy; se, a duas, considerarmos que o exercício dessa "intervenção" da moral no direito estiver a cargo de um juiz (sujeito), que, a partir da consciência de si do pensamento pensante, interprete esses valores e os traga à tona. Para a hermenêutica filosófica esse problema não se apresenta, em face da pré-compreensão, que funciona como uma blindagem contra o relativismo. Do mesmo modo, não penso que esse problema se apresente em Dworkin, exatamente pela necessidade de o juiz obedecer a integridade e a coerência do direito, além deste ter o dever de decidir a partir de argumentos de princípio. A hermenêutica que eu proponho (Crítica Hermenêutica do Direito) forja-se na imbricação dos elementos que caracterizam a tradição em Gadamer com a coerência e a integridade defendidas por Dworkin, culminando na tese de que o cidadão possui o direito fundamental a obter respostas adequadas à Constituição.

Numa palavra: se neoconstitucionalismo quer dizer "imperialismo da moral" no direito ou "moralização do direito" - a partir de discursos que pretendem corrigir exogenamente o direito -, então o neoconstitucionalismo não representa qualquer avanço na teoria do direito e na teoria constitucional. Consequentemente, perderia uma especial característica: o antipositivismo ou pós-positivismo.

Sexta característica - Pós-positivismo: nas palavras de Pozzolo e referidas por Oto na primeira parte da obra, "o Direito do Estado Constitucional, formado (também e sobretudo) por princípios, não seria apto para a aproximação 'rígida' e pouco 'ductil' do método juspositivista, que finalizaria por desatender as exigências de justiça (substancial e não meramente formal) que a realidade prática do direito levaria em si mesmo". Veja-se, de novo, que o embate do neoconstitucionalismo parece ser com o positivismo clássico. Essa minha observação, aliás, é recorrente no presente texto.

Acrescento que, mais do que isso, o pós-positivismo deveria ser a principal característica do neoconstitucionalismo. Deveria, mas não é. Ou seja, o neoconstitucionalismo somente tem sentido enquanto "paradigma do direito" se for compreendido como superador do positivismo ou dos diversos positivismos. Pós-positivismo não é uma continuidade do positivismo, assim como o neoconstitucionalismo não deveria ser uma continuidade do constitucionalismo liberal. Há uma efetiva descontinuidade de cunho paradigmático nessa fenomenologia, no interior da qual os elementos caracterizadores do positivismo são ultrapassados por uma nova concepção de direito. Penso que o ponto fundamental é que o positivismo (e falo não apenas do positivismo exclusivo) nunca se preocupou em responder o problema central do direito, por considerar a discricionariedade judicial como uma fatalidade. A razão prática - que o positivismo chama de discricionariedade - não poderia ser controlada pelos mecanismos teóricos da ciência do direito. A solução, portanto, era simples: deixemos de lado a razão prática (discricionariedade) e façamos apenas 
epistemologia (ou, quando esta não dá conta, deixe-se ao alvedrio do juiz - eis o ovo da serpente gestado desde a modernidade).

Este ponto é fundamental para que fique bem claro para onde as teorias do direito pós-positivistas (ou não positivistas, o que dá no mesmo) pretendem apontar sua artilharia: o enfrentamento do problema interpretativo, que é o elemento fundamental de toda experiência jurídica. Isto significa que, de algum modo, todas as teorias do direito que se projetam nesta dimensão pós-positivista procuram responder a este ponto; procuram enfrentar o problema das vaguezas e ambiguidades dos textos jurídicos; procuram, enfim, enfrentar problemas próprios da chamada razão prática - que havia sido expulsa do território jurídicoepistemológico pelo positivismo ${ }^{18}$. Daí o epíteto pós-positivismo, que se refere à emergência de um novo modelo de teoria do direito, no interior da qual o problema da razão prática recebe uma espécie de "dignidade epistemológica".

Ocorre que este enfrentamento é realizado por vários autores, cada um com orientações jusfilosóficas distintas. Apresento aqui uma espécie de determinação sumária de cada uma destas orientações jusfilosóficas: há um póspositivismo de matriz analítica, que pode ser sentido em autores como Robert Alexy, bem como naqueles que o seguem no modo de sua Teoria da Argumentação Jurídica; podemos notar também uma orientação pós-positivista de cunho discursivo-comunicacional, que se manifesta, obviamente, na Teoria do Direito de Habermas; temos também uma matriz estruturalista, que está presente no pós-positivismo de Friedrich Müller, embora sofra este autor uma grande influência da hermenêutica de corte gadameriano; por fim, há um póspositivismo de matriz hermenêutico-fenomenológico, que está presente nas obras de Ronald Dworkin, Arthur Kaufmann e, em alguma medida, em Josef Esser. Também a minha Crítica Hermenêutica do Direito possui esta raiz filosófica.

Cada uma destas diferentes facetas do pós-positivismo enfrentará o problema da razão prática de uma forma diferente. Este modo de enfrentar o problema tem um profundo impacto em cada uma das teorias, visto que é a partir dele que se projetará o modo pelo qual cuidará de resolver a questão da validade, da legitimidade e, ao mesmo tempo, definirá o significado conceitual de norma, regra, princípio etc.

Para se realizar uma efetiva teoria pós-positivista, dois elementos são, inexoravelmente, necessários: a) ter total consciência do nível teórico sob o qual estão assentadas as projeções teóricas efetuadas, ou seja, uma teoria póspositivista não pode fazer uso de mixagens teóricas, b) enfrentar o problema do solipsismo epistemológico que unifica todas as formas de positivismo.

\footnotetext{
${ }^{18}$ É importante consignar que essa expulsão da razão prática em favor de uma plenipotenciária razão teórica é algo comum, que atravessa ambos os positivismos (tanto o primitivo-legalista; quanto o normativismodiscricionário). Com efeito, aquilo que se iniciou com a codificação e a crença na pura lógica formal para conformação dos sentidos jurídicos chegou ao paroxismo com as construções normativistas (cujo maior exemplo é Kelsen) que chegaram ao ponto de, inclusive, separar os niveis de cientificidade do mundo jurídico.
} 
Nessa medida, é preciso ressaltar que só pode ser chamada de póspositivista uma teoria do direito que tenha, efetivamente, superado o positivismo, tanto na sua forma primitiva, exegético-conceitual, quanto na sua forma normativista, semântico-discricionária. A superação do positivismo implica enfrentamento do problema da discricionariedade judicial ou, também poderíamos falar, no enfrentamento do solipsismo da razão prática. Implica, também, assumir uma tese de descontinuidade com relação ao conceito de princípio. Ou seja, no pós-positivismo, os princípios não podem mais serem tratados no sentido dos velhos princípios gerais do direito, nem como cláusulas de abertura.

Sétima característica - 0 juízo de ponderação: se o pós-positivismo tem sido considerado como o principal elemento diferenciador/caracterizador do neoconstitucionalismo, penso que - e aqui minha discordância com Pozzolo, Oto e Prieto Sanchís, e obviamente, Robert Alexy - a ponderação acabou por se transformar no grande problema e, por assim dizer, em um obstáculo ao próprio neoconstitucionalismo. O neoconstitucionalismo não pode(ria) depender de juízos de ponderação, mormente se percebermos que "ponderação" e "discricionariedade" são faces de uma mesma moeda.

Permito-me delinear minha discordância: como é sabido, a falta de concretização das Constituições programáticas demandou uma reformulação na teoria dos princípios, representada pelo abandono do chamado critério fraco de diferenciação (que considera princípio e regra com a mesma estrutura lógica hipotético-condicional e com diferentes densidades semânticas) para a adoção do critério forte de distinção, onde os princípios assumiam estrutura lógica diferente daquela que identificava a regra. Isso colocou os princípios sob o manto metodológico da ponderação (enquanto que a regra se mantinha na subsunção), permitiu novas possibilidades para os princípios e não demorou muito para que estivéssemos falando em aplicação direta mediante ponderação controlada pela proporcionalidade. Mas o fato é que esse giro não conferiu ao princípio suficiência ôntica-semântica, além de ter mantido intacto o erro originário: o mundo prático foi jogado para "dentro" do sistema e, a partir dessa operação, pensado como tal (como sistema). Ou seja, o mundo prático que é concreto ou, na falta de uma melhor palavra, pragmático, paradoxalmente é retratado ao modo da abstratalidade própria da ideia de sistema. A percepção originária de que os princípios não possuíam densidade semântica conteve, bem ou mal, o avanço do "pamprincipiologismo", mas o equívoco no diagnóstico da crise fez com que os princípios elevassem o grau de discricionariedade, decisionismo e arbitrariedade. A problemática do uso da ponderação ${ }^{19}$ se agrava

\footnotetext{
${ }^{19}$ No modo como a ponderação vem sendo convocada (e "aplicada") em terrae brasilis, tudo está a indicar que não passa daquilo que Philipp Heck chamava, na Jurisprudência dos Interesses, de Abwägung, que quer dizer "sopesamento", "balanceamento" ou "ponderação". Com a diferença de que, na Interessenjurisprudenz, não havia a construção da "regra da ponderação".
} 
com asua extensão às regras ${ }^{20}$ (claro que essa extensão não é endossada por Oto, Pozzolo ou Prieto Sanchis).

De todo modo, o problema principal da ponderação é a sua filiação ao esquema sujeito-objeto e a sua dependência da discricionariedade, ratio final. Desse modo, se a discricionariedade é o elemento que sustenta o positivismo jurídico nos "casos difíceis" e nas vaguezas e ambiguidades da linguagem dos textos jurídicos, não parece que a ponderação seja "o" mecanismo que livre (ou arranque) o direito dos braços do positivismo. Ao contrário, a ponderação não deixa de ser a repristinação - agora de forma sofisticada - da discricionariedade própria das posturas normativistas e de suas variações. Veja-se: a teoria da argumentação - de onde surgiu a ponderação - não conseguiu fugir do velho problema engendrado pelo subjetivismo, a discricionariedade, circunstância que é reconhecida pelo próprio Alexy. ${ }^{21}$

Por tais razões, dizer que a ponderação é um elemento caracterizador do neoconstitucionalismo está correto. Só que isso me afasta sobremodo do neoconstitucionalismo.

Oitava característica - Especificidade interpretativa: segundo parte da doutrina neoconstitucional (por todos, refira-se Comanducci ${ }^{22}$ ), a interpretação da Constituição exigiria especificidades hermenêuticas em relação aos demais "materiais normativos". Também nesse sentido é o dizer de Pozzolo, para quem a linguagem constitucional não é interpretável com os intrumentos comumente utilizados para a interpretação do direito infra-constitucional.

Também aqui há que se fazer um delineamento acerca do lugar do qual estamos falando quando nos referimos à interpretação do direito (ou da Constituição). Se entendermos que a interpretação é uma espécie de ars interpretandi ou uma técnica (método), de fato haveremos de concordar com a afirmativa de Comanducci e Pozzolo.

Mas, por outro lado, se entendermos que interpretar é aplicar (applicatio) e que não há uma subdivisão entre comprender, interpretar e aplicar, então haveremos de concluir que interpretar (portanto, aplicar) é fazer hermenêutica. $\mathrm{E}$ hermenêutica é compreensão, que depende de uma pré-compreensão antecipadora. Portanto, está-se a tratar da interpretação como explicitação da

\footnotetext{
${ }^{20}$ Por todos, vale mencionar Humberto Ávila (Teoria dos princípios. 9. ed. São Paulo: Malheiros, 2009), Luis Roberto Barroso e Ana Paula Barcellos (O começo da história. A nova interpretação constitucional e o papel dos princípios no direito brasileiro. In: BARROSO, Luís Roberto. A nova interpretação constitucional: ponderação, direitos fundamentais e relações privadas. Rio de Janeiro: Renovar, 2003), que sustentam a possibilidade de ponderação de regras.

${ }^{21}$ Cf. ALEXY, Robert. Teoria dos Direitos Fundamentais. Trad. Luis Virgilio A. Silva. São Paulo: Malheiros, 2008, p. 611.

${ }^{22}$ Cf. COMANDUCCI, Paolo. Formas de (neo)constitucionalismo, op. cit., p. 84.
} 
compreensão, isto é, está-se a tratar da interpretação no interior da viragem ontológico-linguística. ${ }^{23}$

Por tais razões, entender que o neoconstitucionalismo exige uma "especificidade interpretativa" é colocar a Constituição como uma mera ferramenta à disposição (Ge-stell) do intérprete, funcionando o método como "supremo momento da subjetividade do intérprete". Se hermenêutica é compreensão, não pode haver diferença entre "compreender infraconstitucionalidades" e "compreender constitucionalidades". Na verdade, compreendemos um fenômeno ou não o compreendemos. E esse fenômeno nos aparece (se manifesta) no interior do círculo hermenêutico: do todo para a parte e da parte para o todo.

\section{Aportes Finais.}

Das características delineadas pelos neoconstitucionalistas e pelos seus críticos - e parece que, no âmago, há um certo consenso em relação a esses elementos conformadores - há algumas auto-evidentes e outras não. Entre as auto-evidentes, estão o "ecletismo", o "judicialismo ético-jurídico", o "imperialismo do interpretativismo moral", a "ponderação", o "estatalismo garantista" e a "especificidade interpretativa". Entretanto, não parecem elementos caracterizadores do neoconstitucionalismo o pós-positivismo e o conceito nãopositivista de direito.

Evidentemente que as características dependem do que se entende por neoconstitucionalismo, mormente se levarmos em conta a questão "positivismo" versus "pós-positivismo". Para tanto, é necessário ter presente se a concepção de neoconstitucionalismo adotada supera - como uma descontinuidade - tanto a noção liberal como a noção de constitucionalismo social; do mesmo modo, há que se indagar se o neoconstitucionalismo deve ser entendido como superador do positivismo jurídico, naquilo que são os seus elementos fundantes no decorrer da história: as fontes sociais, a separação entre direito e moral e o problema da discricionariedade dos juízes. Qualquer desses elementos caracterizadores do positivismo - uma vez não compreendidos - pode colocar por terra a classificação de uma postura em neoconstitucional ou não.

De todo modo, penso que o uso do termo neconstitucionalismo se tornou de tal modo problemático que a melhor opção me parece ser mesmo o seu abandono. A concretização daquilo que se manifesta historicamente como constitucionalismo depende, efetivamente, de uma teoria pós-positivista que, olhando mais de perto, não possui grande semelhança com aquilo que os teóricos do neoconstitucionalismo postulam.

\footnotetext{
${ }^{23}$ Nesse sentido, ver Streck, Verdade e Consenso, op.cit; Jurisdição Constitucional e Decisão Jurídica. São Paulo, RT, 2013, em especial o cap. 6.
} 
Considero que a elaboração de uma teoria pós-positivista tem de levar em conta os seguintes elementos:

I. Há que se ter presente que o direito do Estado Democrático de Direito supera a noção de "fontes sociais", em face daquilo que podemos chamar de prospectividade, isto é, o direito não vem à reboque dos "fatos sociais" e, sim, aponta para a reconstrução da sociedade. Isso é facilmente detectável nos textos constitucionais, como em terrae brasilis, onde a Constituição estabelece que o Brasil é uma República que visa a erradicar a pobreza, etc., além de uma gama de preceitos que estabelecem as possibilidades (e determinações) do resgate das promessas incumpridas da modernidade.

II. Essa problemática tem relação direta com a construção de uma nova teoria das fontes, uma vez que a Constituição será o locus da construção do direito dessa nova fase do Estado (Democrático de Direito); consequentemente, não mais há que se falar em qualquer possibilidade de normas jurídicas que contrariem a Constituição e que possam continuar válidas; mais do que isso, muda a noção de parametricidade, na medida em que a Constituição pode ser aplicada sem a interpositio legislatoris, fonte de serôdias teorias que relativizavam a validade/eficácia das normas.

III. Não pode restar dúvida de que tanto a separação como a dependência/vinculação entre direito e moral estão ultrapassadas, em face daquilo que se convencionou chamar de institucionalização da moral no direito (esta é uma fundamental contribuição de Habermas para o direito: a cooriginariedade entre direito e moral), circunstância que reforça, sobremodo, a autonomia do direito. Isto porque a moral regula o comportamento interno das pessoas, só que esta "regulação" não tem força jurídico-normativa. O que tem força vinculativa, cogente, é o direito, que recebe conteúdos morais (apenas) quando de sua elaboração legislativa.

IV. É evidente que a elaboração legislativa não esgota - nem de longe - o problema do conteúdo do direito. Quando concordamos que as questões morais, políticas, etc., façam parte da "tarefa legislativa", isso não quer dizer que haja, de minha parte - e, por certo, dos adeptos das posições substancialistas - uma viravolta na questão "procedimentalismo-substancialismo". Se as posturas procedimentalistas pretendem esgotar essa discussão a partir da garantia do processo democrático de formação das leis, isso, no entanto, não esgota a discussão da concreta normatividade, locus do sentido hermenêutico do direito. De fato, mais do que apostar na formulação democrática do direito, há que se fazer uma aposta paradigmática, isto é, acreditar na perspectiva pós-positivista do novo constitucionalismo e sua materialidade principiológica. A virtude soberana não se dá simplesmente na formulação legislativa e na "vontade geral". Fundamentalmente, ela será encontrada na Constituição, que estabeleceu uma ruptura com a discricionariedade política que sempre sustentou o positivismo. E isso quer dizer controle da atividade da jurisdição. Na hermenêutica, há um efetivo controle da interpretação a partir da tradição (da autoridade desta), da 
obrigação da integridade, da coerência, da igualdade, da isonomia, enfim, da incorporação dos princípios constitucionais que podemos chamar aqui de virtudes soberanas em homenagem a Dworkin. Por isso, os discursos "predadores" do direito são rechaçados por essa "blindagem hermenêutica" que protege o direito produzido democraticamente. E é exatamente por isso que é possível sustentar respostas adequadas à Constituição, portanto, apostar em uma teoria da decisão e não apenas em uma teoria da legislação. Múltiplas respostas dizem respeito ao relativismo, e, portanto, estão umbilicalmente relacionadas com o positivismo.

Numa palavra final, há uma angústia que perpassa o imaginário dos juristas preocupados com o direito para além de suas clássicas funções. $O$ constitucionalismo engendrado a partir do segundo pós-guerra deu azo ao surgimento de uma teoria cuja função é a de propiciar as condições para a efetiva realização dos conteúdos materiais dos textos normativos (Constituições). Com os qualificativos ou caracterizações que a ela se dê, pode-se dizer, antes de qualquer discussão, que a superação do positivismo - seus problemas, suas insuficiências e suas indiferenças - exigiu, e ainda exige, uma teoria que albergue as diversas posturas que pretendem dar significação e concretização ao novo paradigma constitucional.

\section{Referências}

ALEXY, Robert. Teoria dos Direitos Fundamentais. Trad. Luis Virgilio A. Silva. São Paulo: Malheiros, 2008.

ATIENZA, Manuel. El sentido del derecho. Barcelona: Ariel; 2004.

Sobre Ferrajoli y la superación del positivismo jurídico. In: FERRAJOLI, Luigi; MORESO, José Juan; ATIENZA, Manuel. La teoría del derecho en el paradigma constitucional. Madrid: Fundación Coloquio Jurídico Eoropeo, 2008. 2006.

As razões do direito: teorias da argumentação jurídica. 3. ed. São Paulo: Landy,

Dos versiones del constitucionalismo. In.: Revista de Estudos Constitucionais, Hermenêutica e Teoria do Direito (RECHTD), v. 4, n. 1, janeiro-junho, p. 29-39, 2012. 2009.

; MANERO, Juan Ruiz. Sobre princípios e regras. In: Panóptica, v.4, n.3, p. 49-68,

ÁVILA, Humberto. Teoria dos princípios. 9. ed. São Paulo: Malheiros, 2009

BARBERIS, Mauro. Neoconstitucionalismo, democracia y imperialismo de la moral. In: CARBONELL, Miguel (Org.), Neoconstitucionalismos. Madrid: Trota, 2003. 
BARROSO, Luís Roberto; BARCELLOS, Ana Paula de. O começo da história. A nova interpretação constitucional e o papel dos princípios no direito brasileiro. In: BARROSO, Luís Roberto. A nova interpretação constitucional: ponderação, direitos fundamentais $e$ relações privadas. Rio de Janeiro: Renovar, 2003.

COMANDUCCI, Paolo. Formas de (neo)constitucionalismo. Un análises metateórico. In: CARBONELL, Miguel (Org.). Neoconstitucionalismo(s). Madrid: Trotta, 2003.

HIRSCHL, Ran. O novo constitucionalismo e a judicialização da política pura no mundo. Revista de Direito Administrativo, n. 251, maio/agosto de 2009, pp. 139-175.

MORESO, José Juan. Conflito entre Princípios Constitucionales. In: CARBONELL, Miguel (Org.). Neoconstitucionalismo(s). Madrid: Trotta, pp. 99-121.

STRECK, Lenio Luiz. Hermenêutica Jurídica $e(m)$ crise. 11. ed. Porto Alegre: Livraria do Advogado, 2014.

Jurisdição Constitucional e Decisão Jurídica. São Paulo, RT, 2013.

Verdade e Consenso. 4. Ed. São Paulo: Saraiva, 2011.

TOMÁZ DE OLIVEIRA, Rafael. Decisão Judicial e o Conceito de Princípio: a hermenêutica e a (in)determinação do Direito. Porto Alegre: Livraria do Advogado, 2008. 